\title{
PYROLYSIS OF ELLAJJUN OIL SHALE UNDER THE INFLUENCES OF NITROGEN AND WATER VAPOR
}

\author{
Omar S. Al-Ayed \\ Al-Balqa Applied University, Faculty of Engineering Technology, \\ Department of Industrial Chemical Engineering, P. O. Box, 15008, \\ Marks 11134, Amman, Jordan \\ E-mail: osalayed@fet.edu.jo
}

(Received October 20, 2005 Accepted November 20, 2005)

\begin{abstract}
The pyrolysis of Ellajjun (Jordan) oil shale was carried out in a fixed bed retort in temperature range of $360-550^{\circ} \mathrm{C}$ using either nitrogen or nitrogen-steam mixture as sweeping gas. Differences were observed between the total weight loss and product compositions. Pyrolysis under nitrogen-steam mixture gave larger increase in weight loss as pyrolysis temperature increased.

The retorted shale oil samples under the influence of either nitrogen or nitrogen-steam were distilled. The gasoline- naphtha and kerosene fractions from simple atmospheric distillation, were increased by $35 \%$ and $65 \%$ (vol.) respectively while, diesel fraction was decreased by $45 \%$ vol. compared with nitrogen pyrolysis.
\end{abstract}

KEY WORDS: Oil shale, fixed bed, retort, weight loss, distillation

\section{INTRODUCTION}

With increasing number of countries experiencing decline in conventional oil production, and in the wake of souring oil pricing beyond US $60 \$$ per barrel, it has become imperative for governments that have large proved deposits of oil shale to explore the various utilization methods. In China, as an example, Fushun Oil Shale Retorting Plant - came into operation in 1992 under the management of the Fushun Bureau of Mines. Its 60 retorts annually produce 60000 tones of shale oil to be sold as fuel oil, with carbon black as a by-product.

Jordanian shales are generally of quite good quality, with relatively low ash and moisture contents. Gross calorific value $(7.5 \mathrm{MJ} / \mathrm{kg})$ and oil yield $(8-12 \%)$ are on a par with those of western Colorado (USA) shale. However, Jordanian shale has exceptionally high sulfur content (up to $9 \%$ by weight of the organic content). The reserves are exploitable by opencast mining and are easily accessible. There are extremely large proven and exploitable reserves of oil shale in the central and northwestern regions of the country. The proved amount of oil shale in place is reported bye WEC Member Committee to be 40 billion tons; proved recoverable reserves of shale oil are put at 4 billion tons, with estimated additional reserves of 20 billion tons. 
Pyrolysis of Ellajjun oil shale has been studied by several researchers using fixed bed retort [2] and fluidized bed reactor [3-5]. Those workers have used nitrogen to drive out the generated hydrocarbons and volatile matter out of the reaction zone.

In this research, we have investigated the influence of nitrogen and nitrogen-steam (water vapor) as sweeping gases on reactions and product distribution during pyrolysis of oil shale in $360-550^{\circ} \mathrm{C}$ temperature range. The distribution of shale oil fractions distilled at atmospheric pressure, are compared.

\section{EXPERIMENTAL WORK}

Oil shale samples from Ellajjun area southern region of Jordan were studied and investigated in this work. The characteristics and analyses of the raw oil shale samples are given in Table 1.

The original oil shale samples, were ground in a ball mill, and sieved to the particle size $\left(\mathrm{d}_{\mathrm{p}}\right), 0.5<\mathrm{d}_{\mathrm{p}}<2 \mathrm{~mm}$. Oil shale analyses were performed in the National Energy Research Center (Jordan). All samples were dried at $383 \mathrm{~K}$ for a period of two hours prior to the course of experiments.

All experiments were conducted in a stainless steel fixed bed reactor. A $600 \mathrm{~g}$ of oil shale sample was electrically heated in $800 \mathrm{~cm}^{3}$ volume cylindrical retort. Nitrogen gas feed rate was maintained at $150 \mathrm{~cm}^{3}$ per minute. The pyrolysis runs were conducted in the temperature range of 360 to $550^{\circ} \mathrm{C}$. To fractionate shale oil in a simple atmospheric distillation, $500 \mathrm{~cm} 3$ were needed for each temperature. The required quantities of oil for distillation were collected at selected temperatures of, $470,490,510^{\circ} \mathrm{C}$ since the oil yield is more at high temperatures. In nitrogen-steam (water vapor) runs, the nitrogen was bubbled in distilled water for saturation and allowed into the reaction zone after preheating. The evolved hydrocarbon and the non-condensable gases were passed through condenser maintained at $0^{\circ} \mathrm{C}$. The non-condensable gases were vented to atmosphere and the collected hydrocarbon were measured and distilled.

Table 1: Characteristics analysis (\% by weight) of the oil shale samples.

\begin{tabular}{|l|c|c|c|}
\hline \multicolumn{1}{|c|}{ Component } & Raw Shale & $\begin{array}{c}\text { Spent Shale } \\
\text { (nitrogen) }\end{array}$ & $\begin{array}{c}\text { Spent Shale (nitrogen- } \\
\text { steam) }\end{array}$ \\
\hline Moisture Content & 1.21 & 0.39 & 0.53 \\
\hline Total Water & 3.4 & --- & --- \\
\hline Total Oil & 9.6 & --- & --- \\
\hline Gas Loss & 3.4 & --- & --- \\
\hline Spent Shale & 86.3 & --- & --- \\
\hline Total Sulfur & 2.29 & 0.804 & 0.71 \\
\hline Total Carbon & 17.28 & 12.6 & 10.32 \\
\hline Total Organic Carbon & 11.42 & 5.72 & 3.27 \\
\hline Hydrogen & 1.764 & 0.593 & 0.359 \\
\hline CaCO 3 & 46.31 & 56.27 & 61.32 \\
\hline Calorific Value, $\mathrm{kJ} / \mathrm{kg}$ & 5487 & 1748 & 1254 \\
\hline
\end{tabular}




\section{RESULTS AND DISCUSSION}

The effects of various process variables such as pyrolysis temperature and type of sweep gas on the oil shale decomposition and product distribution were investigated in this study. The effect of pyrolysis temperature on oil yield based on Fisher assay is depicted in Figure 1. As it can be seen, the oil yield increases with increasing pyrolysis temperature for both nitrogen and nitrogen-steam mixture sweep mediums to a maximum value at $490^{\circ} \mathrm{C}$. A decrease in oil yield is observed for higher temperatures as shown in the same figure. This decrease is more for nitrogen-steam mixture compared with nitrogen medium. These results are in agreement with the results reported by El harfi et.al [6].

The impact of increasing temperature on the rate of Kerogen decomposition was measured as total weight loss \% of sample. It is well known [2] that increasing the pyrolysis temperature increase the rate of Kerogen decomposition as well as increases the total weight loss \%. The total sample weight loss is more when nitrogen-steam mixture was used compared with nitrogen sweep gas at $490^{\circ} \mathrm{C}$ as indicated in Figure 1. As it can be seen, the weight loss $\%$ is higher in case of nitrogen-steam mixture compared with nitrogen runs.. These results are in agreement with earlier works of Elharfi [7]. As reaction temperature is increased, the differences in weight losses are more under nitrogen-steam mixture condition. The increase in the difference is attributed to steam reactions with organic matter of the oil shale [8]. Furthermore, the presence of water vapor aids the evaporation of oils from the shale and reduces coke formation [9]. It may also favor the distillation and desorption of low molecular weight products entangled in the mineral matrix [10-12]. These explanations are supported in this study by presence of $31 \% \mathrm{CaO}$ and $9 \% \mathrm{SiO}_{2}$ materials in the Ellajjun oil shale which enhance the hydrocarbon cracking reactions [2]. In a complex reacting system such as oil shale decomposition, as the reaction temperature is increased the catalytic effect of these materials is more significant at high pyrolysis temperature rather than low temperature.

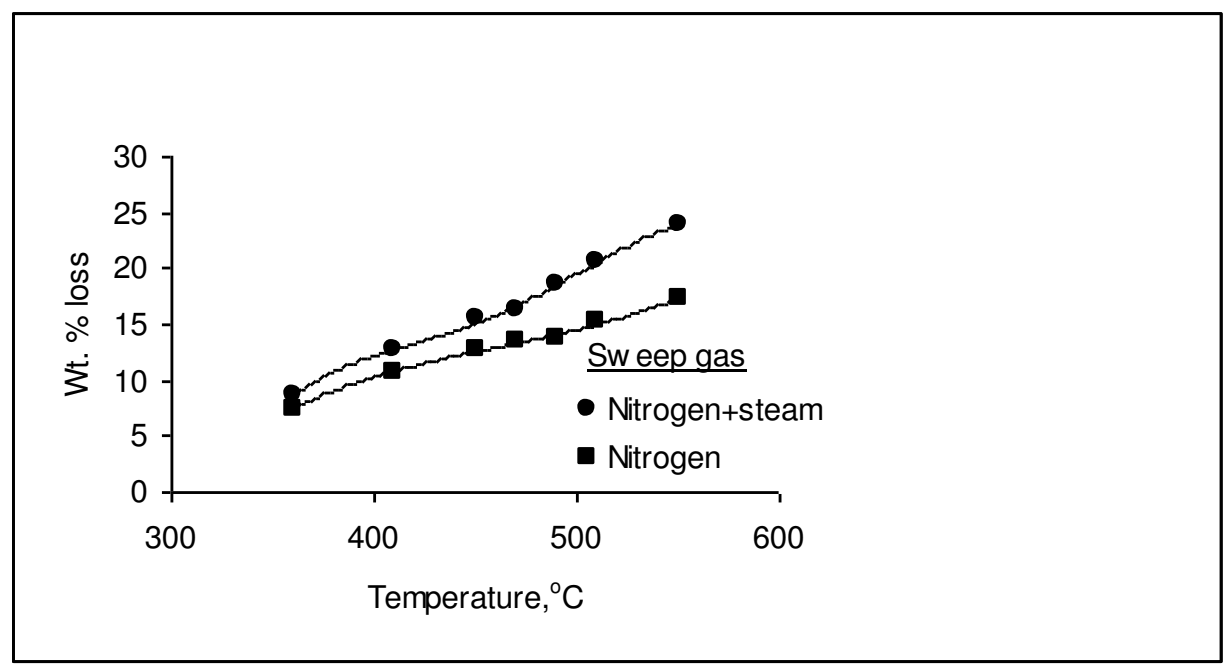

Fig. 1: Effect of pyrolysis temperature on total weight \% loss. 
The influence of the reaction temperature on the oil yield for different sweep gases is shown in Figure 2. It is quite clear, that the oil yield based on Fisher assay, is higher for nitrogen-steam mixture sweep gas than that of nitrogen. As it can be seen from the figure, the maximum oil yield percent is obtained at $490^{\circ} \mathrm{C}$ pyrolysis temperature for the sweep gases. Similar behavior is observed for other oil shales $[6,13]$. For both sweep gases, the oil yield decreased for temperatures higher than $490^{\circ} \mathrm{C}$. This effect, is more clear and pronounced in the case of nitrogen-steam mixture. As indicated earlier, the presence of steam and the catalytic effect of alumina and silica oxides enhance oil cracking and gasification reactions and subsequently more of total weight loss for nitrogen-steam environment.

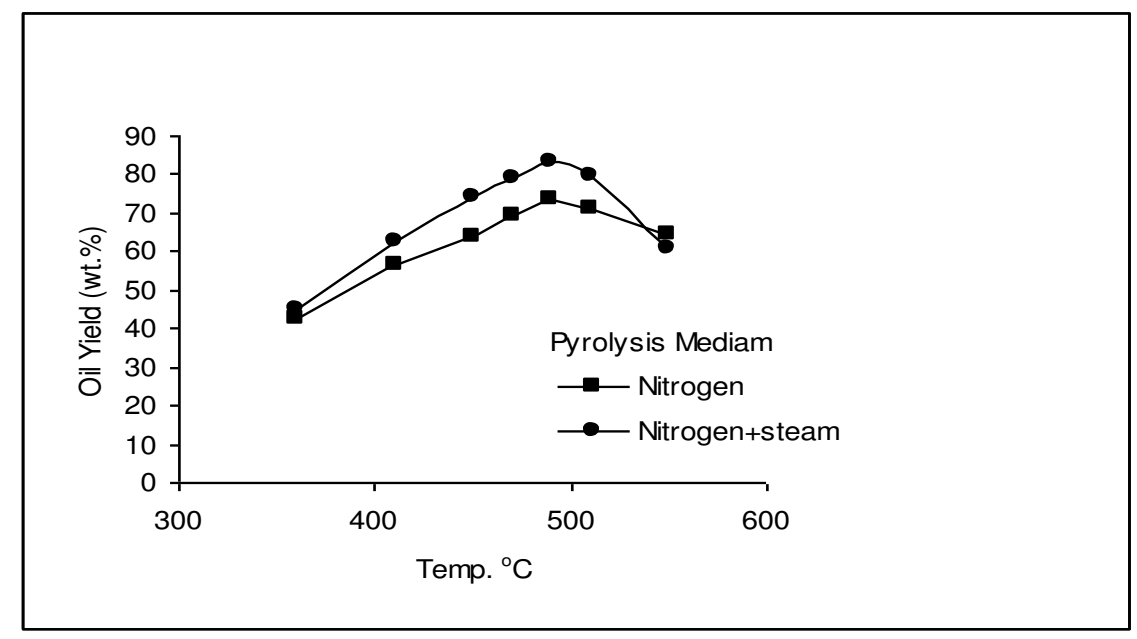

Fig. 2: Influence of the pyrolysis temperature on oil yield.

The generated liquid products were taken to simple atmospheric distillation apparatus in the Jordan Petroleum Refinery. The result of shale oil fractionation is shown in Figure 3 in which the effect of pyrolysis medium on the product distribution at constant pyrolysis temperature is depicted. The data are collected at $490^{\circ} \mathrm{C}$ reaction temperature for nitrogen and nitrogen-steam sweep gases. From the figure, it can be seen that, nitrogen-steam sweep gas reaction environment resulted in the production of lighter hydrocarbon fraction compared with nitrogen sweep gas medium, i.e. the volume $\%$ distilled is higher for same distillation temperature. Also, the lower molecular weight hydrocarbons volume \% distilled is larger as distillation temperature is increased till $330^{\circ} \mathrm{C}$, whereas, at higher temperatures, both the sweep gases produced liquids of similar composition at same distillation temperature. These results are in good agreement with the work of El-harfi et.al [6, 7]. These authors, reported n-alkanes ranges from $n \mathrm{C}_{13}$ to $n \mathrm{C}_{35}$ for the pyrolysis under water vapor while it ranged form $n \mathrm{C}_{16}$ to $n \mathrm{C}_{35}$ in the case of nitrogen sweep gas pyrolysis, suggesting large fraction of lighter hydrocarbon. This increase is ascribed to the effect of steam in accelerating products diffusion out of the mineral matrix of oil shale and breaking bonds (such as hydrogen bond, donor-acceptor interaction, and the weak carbon-halogens bonds) within the macromolecular complex [15]. 


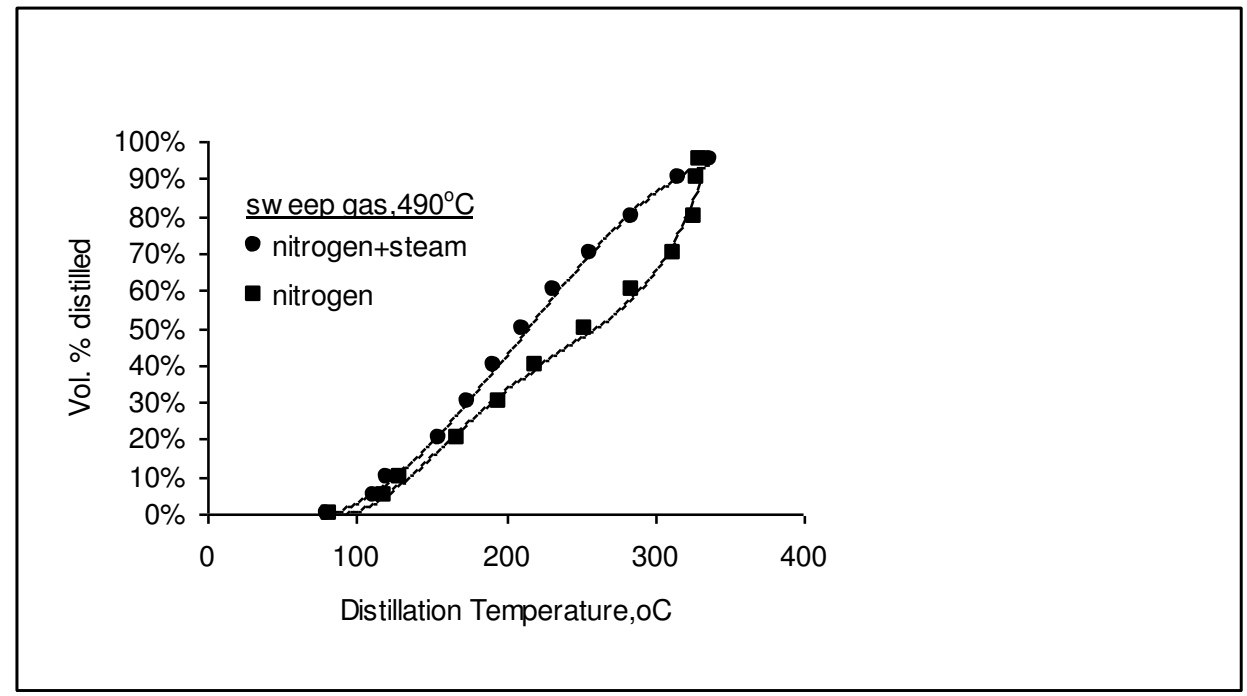

Fig. 3: Volume distilled vs. distillation temperature.

The result of simple atmospheric distillation for shale oil sample produced at $490^{\circ} \mathrm{C}$ in presence of nitrogen and nitrogen-steam environment is shown in Figure 4. It is clear from the column chart representation that the effect of nitrogen-steam on the product distribution is pronounced. It is known that the petroleum fractions are characterized by the boiling range, in this case, Gasoline and Naphtha boiling range is taken to be $0^{\circ} \mathrm{C}$ to $140^{\circ} \mathrm{C}$, while Kerosene boiling range is $140^{\circ} \mathrm{C}-250^{\circ} \mathrm{C}$ and the Diesel fraction boils in the range $250^{\circ} \mathrm{C}-370^{\circ} \mathrm{C}$. According to these boiling ranges, the increment in the amount of gasoline and naphtha volume produced due to the

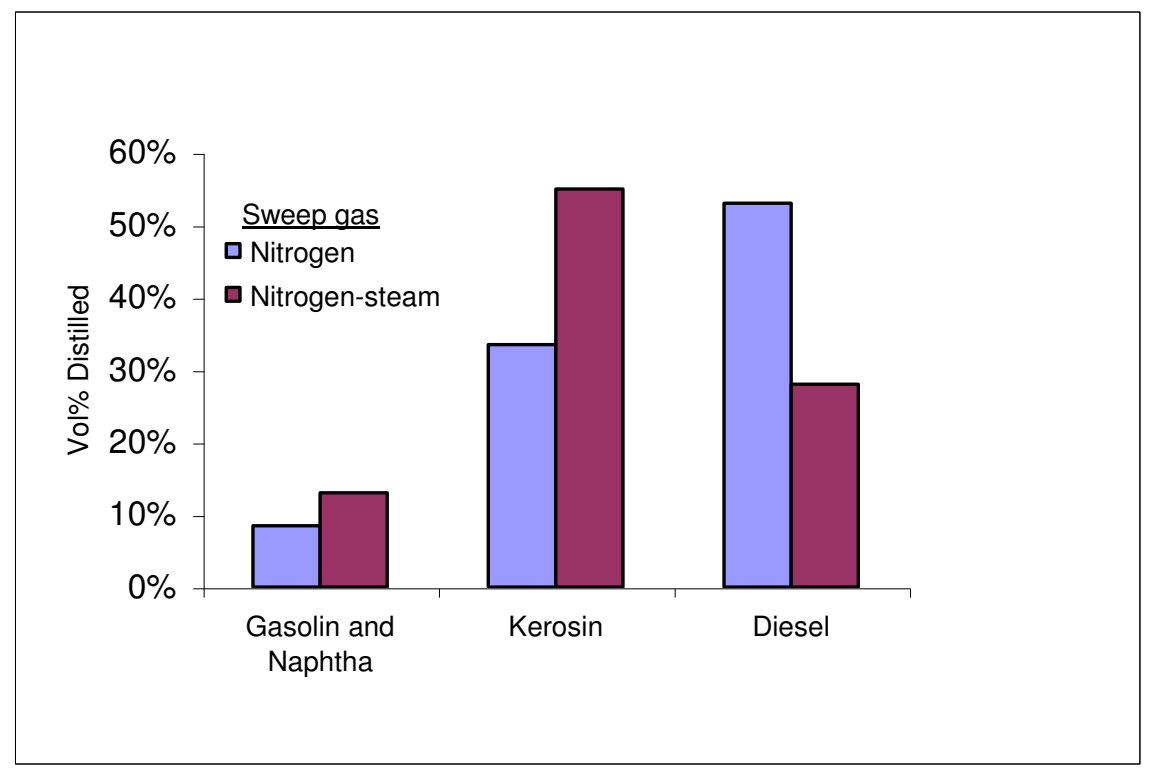

Fig. 4: Fractionation of products vs. volume \% distilled. 
presence of steam has increased to $14 \%$ as compared with $9 \%$ with nitrogen sweep gas. This $55 \%$ volume increase is due to the production of more of lighter hydrocarbon in presence of water vapor during pyrolysis. On the other hand, the Kerosene fraction has risen to $56 \%$ from $34 \%$; i.e. $22 \%$ volume.

These results are in excellent agreement with the explanation furnished with other investigators $[6,10]$. The increase in the volume percent of the lighter fractions of the products is commensurate with the decrease for hydrocarbon produced. It can be seen from figure 4 that the volume percentage of the diesel fraction has decreased from $52 \%$ to $27 \%$, i.e. $50 \%$ reduction in the amount produced. This augments the role of steam in reducing coking, polymerization and enhancing cracking reactions of long hydrocarbon molecules. The residual of the distillation operation above $370^{\circ} \mathrm{C}$ did not exceed $5 \%$ on volume basis, suggesting that very less of heavy petroleum product is produced during pyrolysis of Ellajjun oil shale.

\section{CONCLUSIONS}

The experimental results of this work show that the total weight losses of various samples were higher for nitrogen-steam than nitrogen pyrolysis runs. Oil yield obtained for the nitrogen and nitrogen-steam carries gases during pyrolysis of Ellajjun oil shale attains a maximum at $490^{\circ} \mathrm{C}$ temperature. Higher oil yields were achieved under the influence of nitrogen-steam mixture when compared with nitrogen sweep gas for same pyrolysis temperatures. However, for higher reaction temperature, $\mathrm{T}>530^{\circ} \mathrm{C}$ the oil yield declined so that the nitrogen sweep gas oil yield is higher than that of nitrogen-steam mixture. Cracking and gasification of hydrocarbons in presence of steam were the main reactions responsible for the production of lighter hydrocarbons.

The effect of water vapor presence in the pyrolysis environment resulted in the production of lighter components than nitrogen sweep gas. The gasoline-naphtha fraction increased by $55 \%$ volume during nitrogen-steam pyrolysis condition compared with nitrogen as sweep gas. In contrast, the percent volume increase is less for kerosene fraction by $22 \%$ with respect to that of nitrogen carrier gas. These product alterations are the results of coke formation inhibition and cracking reaction enhancement due to presence of water vapor which lead to a decrease in the volume percent of diesel fraction produced. The total decrease in diesel volume percent fraction was $50 \%$.

\section{REFERENCES}

[1] World Energy Report (WER), 2001.

[2] O.S. Al-Ayed, Journal of Engineering Science, 33, No.4, (2005), 1477-1485

[3] J.M. Nazzal and P.T. Williams, , Int. J. Energy Res. 26, (2002), 1207-1219

[4] J.O. Jaber, S.D. Probert, and P.T. Williams, Energy, 24, (1999), 761-781

[5] J.O. Jaber, S.D. Probert , Applied Energy, 63, (1999), 269-286

[6] K. El harfi, A. Mokhlisse, M. Ben Chanaa, J. of Anal. and Appl. Pyrolysis, 56, (2000),207-218

[7] K. El harfi, , A. Mokhlisse, M. Ben Chanaa, J. of Anal. and Appl. Pyrolysis, 48, (1999), 65-76

[8] S.D. Carter, D.N. Taulbee, Fuel Proc. Technol. 3, (1985), 251-263 
[9] M. Ciritoglu, C.E. Snape, C.J. Lafferty, E. Ekinic, K.D. Bartle, Erdol Kohle Erdgas Petrochim. Brennst. Chem. 43(1990), 442-451

[10] Dung N.V., Fuel 69 (1990), 368-375

[11] V. Minkova, M. Rasvigorova, M. Goranova, L. Ljutzkanova, G. Angelova , Fuel, 70 (1991), 713-725

[12] M. Rasvigorova , M. Goranova , V. Minkova , L. Ljutzkanova , G. Angelova , fuel, 74 (1995), 1333-1340

[13] S. D. Carter, D.N. Taulbee, Fuel, 11(1985), 251-259

[14] E. Ekinci , M. Ciritoglu , E. Putun , G.D. Love , C.J. Snape , Fuel, 71,(1992), 1511-1519

[15] National Energy Research Development and Demonstration Program. "Integrated processing of Australian Oil Shale", Report, 1990

\section{تحطيم الصخر الزيتي من منطقة اللجون تحث تأثير النيتروجين وبخار الماء منطوة}

تم تحطيم الصخر الزيتي من منطقة اللجون (الأردن) في مقطرة ذو طبقة ثابتة

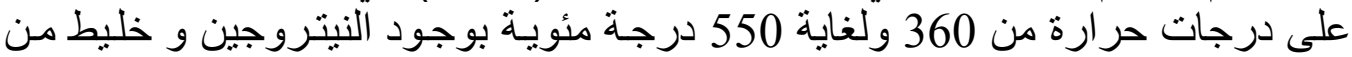

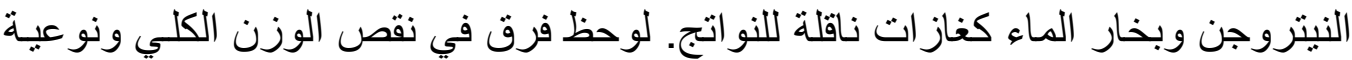
الناتج البترولي.كانت كمية التقطير بوجود خليط من النيتروجن وبخار الماء اكبر منه في



عند تقطير الزيت المنتج تحت تأثير النيتروجن وبخار الماء في برج تقطير بسيط،

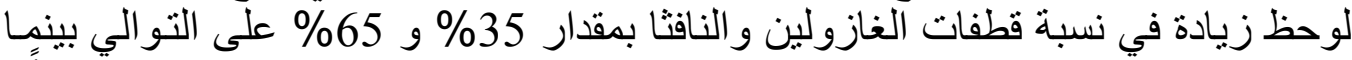
قطفة الديزل نقصت بنسبة 45\% مقارنة مع الزيت المستخرج بوجود النيتروجن منفرداً. 